\title{
SOCIOLOGICAL ANALYSIS OF EDUCATION AND REDUCTION IN FAMILY SIZE IN KHYBER PAKHTUNKHWA-PAKISTAN
} Muhammad Jawad ${ }^{1}$, Aman Ullah ${ }^{2 *}$, Saima Sarir ${ }^{3}$, Seema Zubair ${ }^{4}$, Alamgeer Khan ${ }^{5}$

${ }^{1,3,5}$ Lecturer, Department of Rural Sociology, The University of Agriculture, Peshawar, Pakistan; ${ }^{2 *}$ Head of Department/Lecturer, Department of Sociology, University of Swabi, Swabi, Khyber-Pakhtunkhwa, Pakistan; ${ }^{4}$ Lecturer, Department of Statistics, Mathematics and Computer Science, The University of Agriculture Peshawar, Khyber Pakhtunkhwa, Pakistan.

Email: ${ }^{1}$ mjawadukhel@aup.edu.pk, ${ }^{2 *}$ aman@ ${ }_{5}$ oswabi.edu.pk, ${ }^{3}$ drsaimasarir@aup.edu.pk, ${ }^{4}$ seemazubair@aup.edu.pk, 5alamgeer@aup.edu.pk

Article History: Received on $13^{\text {th }}$ February 2021, Revised on $11^{\text {th }}$ March 2021, Published on $22^{\text {nd }}$ March 2021

\begin{abstract}
Purpose of the study: The present study examines the association between education and reduction in family size in district Peshawar.

Methodology: The results are based on the data gathered from 384 sampled respondents belonging to 6 communities that included 3 each from rural and urban areas of District Peshawar. The chi-square test was applied for statistical analysis.

Main Findings: The study found a positive trend among the sampled families towards the decrease in family size which found the norm in the selected area where many respondents were still considering a large number of children as the blessing of Almighty Allah. The major role this regard was played by the education of the sampled respondents through generating more awareness about small family size along with increased exposure to norms favoring a decrease in family size. It was also influenced by more communication among the sampled couples. The education further enabled the sampled respondents to get more information about family planning and the institutions designed to promote family planning in Pakistan. It ultimately motivated the respondents to use contraceptives to decrease family size.
\end{abstract}

Applications of this study: The study recommends promoting and enhancing the trend through a campaign for bringing a change in the attitude and action of the people towards making a family size required for the country.

The originality of this study: This study will be helpful for policy Implications.

Keywords: Family Size, Fertility, Education, Sociological Analysis, Rural and Urban Areas.

\section{INTRODUCTION}

Education is generally a process of facilitating learning, or the acquisition of knowledge, skills, values, beliefs, and habits, however, it is also imparted to bring specific changes in the society either directly or indirectly. Educated people are more prone to change than no or low educated. The acceptance of new ideas or realization of a problem is very high among the educated people as well. This made education especially at the Primary level as the eighth universal goal of international Millennium Development. High population growth or large family size is the other major issue world is dealing with at the moment. It has been controlled in the developed world mostly whereas consistently found high in the developing countries even in the beginning of the 21 st century. Education along with more awareness, access to family planning services, and adoption of family planning methods are the major causes of population control in the world (Götmark \& Andersson, 2020; Mandl, 2019; Steer \& Wathne, 2010; Tropf \& Mandemakers, 2017; Ullah, Ashraf, Tariq. Aziz, Sikandar, et al., 2021).

The role and importance of education in connection with the improvement in enabling people to decide family size are acceptable throughout the world (Kakar, et al., 2011). A decrease in fertility level is found with a constant increase in the levels of education. Family size among the primary level educated couples was 2.9 compared to 5.4 among the illiterates. The same was reported in Egypt, Syria, and Morocco (Berrington \& Pattaro, 2014; Martin, 1995) .Similarly, a 26 percent increase in female literacy decreased the fertility rate by 70 percent (Bhargava, 2003). The most significant beneficiaries of education are the females. The factors affecting the reduction in family sizes such as delay in marriage, use of contraceptives, involvement in off-farm work, more attention to family health, education, and ideal family size are found high among the educated couples (Basu, 2002; Bauer \& Kneip, 2014; Berrington \& Pattaro, 2014; Gwako, 1997; Marcén, Molina, \& Morales, 2018). In the past few decades, the number of children born to educated mothers has declined. Females with just a primary school education witness the largest decline in this regard. Women of other types of schooling are also seeing a decline (Kaboudi, Ramezakhani, Manouchehri, \& Hajizadeh, 2013). Education is the most powerful investment that will radically change the world for the better. Many countries around the world are now cantered on education as a way of enhancing monetary growth, encouraging smaller household sizes through the use of cutting-edge contraceptive techniques, and offering acceptable fitness care to moms and infants. According to the latest study, there is a correlation between female education and their capacity to raise children, as women with more education are more likely to have a small family and have access to better health care. Fertility fell by $20 \%$ for women with seven or more years of schooling (Jejeebhoy, 1995; Lloyd, Kaufman, \& Hewett, 2000; Sámano et al., 2019). 
Furthermore, after finishing their studies, many women defer marriage and use family planning methods ensuing in smaller families (Akmam, 2002). Education also helps couples to follow a new and leisurely lifestyle, which in India, China, and many African countries necessitates preparing and achieving smaller families (Murthi, 2002). In fact, it not only allowed them to prepare but also retain a restricted family size (Mari Bhat, 2002). Gender justice and women's education are two major motives that affected fertility decline. Women, in particular, were granted the right to make decisions about household matters, including the size of their households, as a result of their education. Furthermore, qualified women do not have time for multiple childbearing, and education often decreases female dependency on sons in old age (Basu, 1999, 2002; Pirinçci \& Oguzöncül, 2008). Overall, Carl (2006) put forwards that if schooling is readily available, fertility will decline rapidly. If a large part of a society's workforce is educated in school, such a limited amount of education will have a significant effect on population growth.

Keeping in mind the above fact the present study is aimed to explored factors affecting family size in the study area.

\section{RESEARCH METHODOLOGY}

The present study was conducted in District Peshawar through a Cross-sectional study design to observe the phenomena behind family size in Pakistan. A sample size of 384 respondents was selected based on the simplified procedure designed by Sekaran and Bougie (2016) and Cooper, Schindler, and Sun (2006) sample size formula.

$$
n=\frac{p q}{\sigma p^{2}}
$$

Where $\mathrm{n}$ was a sample size, pq measured the sample dispersion and $\sigma \mathrm{p}$ was a standard error of the proportion. In addition, from each selected area sample size was derived through the Proportionate sampling method. Data were collected through a comprehensive questionnaire/ interview schedule. After data collection it was coded entered into the computer, SPSS was used for the analysis of data at Uni and Bi-Variate levels. Moreover, analysis in this respect was made by using Chi-Square and Fisher Exact tests See (Ullah \& Muhammad, 2020). The formula used to compute Chisquare is given in the following:

$$
x^{2}=\sum_{i=1}^{r} \sum_{j=1}^{c} \frac{\left(O_{i j}-E_{i j}\right)^{2}}{E_{i j}}
$$

Further, Fisher exact test was also carried out. The formula of the said test is explained below.

Fisher Exact Test $=\frac{(a+b) !(c+d) !(a+c) !(b+d) !}{N ! a ! b ! c ! d !}$

\section{RESULTS AND DISCUSSION}

\section{Small Family Size}

Findings regarding small family size in Pakistan are presented in table 1. Less than half of 46.1 percent of the study participant reported that family size from the last 20-25 years has declined. More than half of 57 of the respondents reported a decline in family size in their families. These findings are closely in line with the previous empirical work of (Morita, Ohtsuki, Sasaki, \& Hiraiwa-Hasegawa, 2012). A decline in the family was triggered by many factors, for instance, 67.4 percent of the total sample size opined that small family is a norm now a day, and a third-fifth of the respondents 69.5 percent preferred small family size over the large one. About three-fourths $74 \%$ of the respondents considered 2-4 children were ideal family size. Likewise, 71.1 percent of the study participant stated that small family size has a better future. Moreover, 79.2 percent of the respondents stated it is better to have less but productive children instead of unproductive ones. About two-fourths 48.7 percent of the respondents stated that people feel shame in describing if family size is large. The abovementioned findings are closely in line with the empirical work of (Owuamanam \& Alowolodu, 2010; Sikandar, Khwaja, Shaikh, \& Jatoi, 2012).

Taking together the abovementioned findings and prior empirical work it could be inferences that a strong orientation of the study participant towards the decline infertility. Moreover, the small family size was explored as a norm where 2-4 children were called as ideal family size and less family size is a determinant of the better future for the children in society.

Table 1: Small Family Size

\begin{tabular}{llllll}
\hline $\begin{array}{l}\text { S. } \\
\text { No. }\end{array}$ & Statement & Yes & No & Uncertain & Total \\
\hline 1. & $\begin{array}{l}\text { Family size in Pakistan is on the decline for the last 20 to 25 } \\
\text { years. }\end{array}$ & $177(46.1)$ & $101(26.3)$ & $106(27.6)$ & $384(100)$ \\
\hline 2. & There is a decline in the size of the family in your family. & $219(57.0)$ & $138(35.9)$ & $27(7.0)$ & $384(100)$ \\
\hline 3. & Small family size is a norm nowadays. & $259(67.4)$ & $93(24.2)$ & $32(8.3)$ & $384(100)$ \\
\hline 4. & You prefer a small family size over a large one. & $267(69.5)$ & $85(22.1)$ & $32(8.3)$ & $384(100)$ \\
\hline 5. & More children are the blessing of God. & $336(87.5)$ & $24(6.3)$ & $24(6.3)$ & $384(100)$ \\
\hline
\end{tabular}




\begin{tabular}{llllll}
\hline 6. & 2-4 children are nowadays considered as an ideal family size & $284(74.0)$ & $67(17.4)$ & $33(8.6)$ & $384(100)$ \\
\hline 7. & People feel shame in describing if family size is large. & $187(48.7)$ & $165(43.0)$ & $32(8.3)$ & $384(100)$ \\
\hline 8. & $\begin{array}{l}\text { It's better to have less but productive children than more } \\
\text { unproductive ones. }\end{array}$ & $304(79.2)$ & $59(15.4)$ & $21(5.5)$ & $384(100)$ \\
\hline 9. & Small family size has a better future. & $273(71.1)$ & $55(14.3)$ & $56(14.6)$ & $384(100)$ \\
\hline
\end{tabular}

\section{Education}

Information regarding education and family size is reported in table 2. Most of the $89.3 \%$ of respondents stated that uneducated females have a large family size. In addition, more than third-fourth (76.6\%) of the sample size opined that illiterate couples follow the traditions more than the literate ones who had a positive orientation towards low fertility disclosed by 81.0 percent of the study respondents. These findings were also supported by (Åslund \& Grönqvist, 2010; Kamal \& Pervaiz, 2011). Furthermore, most of the respondents (83.6\%) stated that the use of contraceptives among educated couples is high and they are more aware of the negative effects of high family size answer by (88.0\%) of the sample size. Furthermore, most of the respondents (83.6\%) stated that educated couples have more communication with one another about family size, and they have more exposure regarding new values or ideas and family size pointed out by more than third-fourth $76.8 \%$ of the respondents. Notwithstanding, $(83.1 \%)$ of the study participant disclosed that adoption of family planning methods earlier than the illiterate couples. Similar findings were also explored by (Borenstein, Kendal, \& Feldman, 2006; Ihara \& W. Feldman, 2004).

The table as a whole concludes that education is inversely associated with high family size. Besides, family size among the literate couples was low because of exposure, awareness, and access to family planning services.

Table 2: Education and Family Size

\begin{tabular}{llllll}
\hline $\begin{array}{l}\text { S. } \\
\text { No. }\end{array}$ & Statement & Yes & No & Uncertain & Total \\
\hline 1. & Family size among the uneducated is usually high. & $343(89.3)$ & $26(6.8)$ & $15(3.9)$ & $384(100)$ \\
\hline 2. & Illiterate couples follow traditions more than the literates. & $294(76.6)$ & $68(17.7)$ & $22(5.7)$ & $384(100)$ \\
\hline 3. & $\begin{array}{l}\text { There is a positive orientation towards small family size among } \\
\text { the educated males. }\end{array}$ & $311(81.0)$ & $43(11.2)$ & $30(7.8)$ & $384(100)$ \\
\hline 4. & Contraceptive use is high among the educated couples. & $321(83.6)$ & $40(10.4)$ & $23(6.0)$ & $384(100)$ \\
\hline 5. & $\begin{array}{l}\text { Educated couples have more awareness about the effects of } \\
\text { family size. }\end{array}$ & $338(338)$ & $29(7.6)$ & $17(4.4)$ & $384(100)$ \\
\hline 6. & $\begin{array}{l}\text { Educated couples have more communication with one another } \\
\text { about family size. }\end{array}$ & $321(83.6)$ & $29(7.6)$ & $34(8.9)$ & $384(100)$ \\
\hline 7. & $\begin{array}{l}\text { Educated couples are more exposed to new values or ideas } \\
\text { regarding family size. }\end{array}$ & $295(76.8)$ & $40(10.4)$ & $49(12.8)$ & $384(100)$ \\
\hline 8. & Educated couples have more access to family planning services. & $319(83.1)$ & $24(6.3)$ & $41(10.7)$ & $384(100)$ \\
\hline 9. & Educated couples adopt contraceptives earlier than illiterate. & $320(83.3)$ & $29(7.6)$ & $35(9.1)$ & $384(100)$ \\
\hline
\end{tabular}

\section{Association between Education and Small Family Size}

The relationship between education and family size is ascertained through a Chi-secure test. The result of the study shows that that family size among uneducated people is usually high observed significant $(0.012)$. Likewise, illiterate couples follow traditions more than the literates found highly significant $(0.000)$. Moreover, positive orientation towards small family size among the educated males is observed highly significant $(0.000)$. These findings are closely in line with the work of (Kamal \& Pervaiz, 2011). Moreover, contraceptive use is found highly (0.000) with family size. Likewise, more awareness about the effects of family size is also observed as highly significant $(0.000)$ with family size. Besides, communication with one another about family size was observed highly significant $(0.000)$ with family size. Notwithstanding, exposure to new values or ideas regarding family size discover highly significant $(0.000)$ with family size. Besides, access to family planning services (0.000) and adoption of contraceptives earlier than illiterate couples $(0.000)$ also observed highly significant with family size. The findings are consistent with the following empirical work of (Ihara \& W. Feldman, 2004; Kakar, Khilji, \& Ullah, 2011; Kamal \& Pervaiz, 2011; Ullah, Ashraf, Tariq, Aziz, Zubair, et al., 2021).

Table 3: Association between Education and Small Family Size

\begin{tabular}{|c|c|c|c|c|c|}
\hline \multirow[t]{2}{*}{ S. No } & \multirow[t]{2}{*}{ Statement } & \multicolumn{3}{|c|}{ Small Family Size } & \multirow[t]{2}{*}{$\begin{array}{l}\text { Chi-square } \\
P=\text { value }\end{array}$} \\
\hline & & Yes & No & Uncertain & \\
\hline \multirow[t]{4}{*}{1.} & Family size among & Ineducated $\mathrm{p}$ & rsons is us & ally high & \\
\hline & Yes & $216(56.2)$ & $87(22.7)$ & $40(10.4)$ & \multirow[t]{3}{*}{$x^{2}=12.819(\mathrm{p}=0.012)$} \\
\hline & No & $15(3.9)$ & $8(2.1)$ & $3(0.8)$ & \\
\hline & Uncertain & $4(1.0)$ & $5(1.3)$ & $6(1.6)$ & \\
\hline
\end{tabular}




\begin{tabular}{|c|c|c|c|c|c|}
\hline \multirow[t]{4}{*}{2.} & \multicolumn{5}{|c|}{ Illiterate couples follow traditions more than the literates } \\
\hline & Yes & $200(52.1)$ & $68(17.7)$ & $26(6.8)$ & $x^{2}=32.370(\mathrm{p}=0.000)$ \\
\hline & No & $30(7.8)$ & $21(5.5)$ & $17(4.4)$ & \\
\hline & Uncertain & $5(1.3)$ & $11(2.9)$ & $6(1.6)$ & \\
\hline \multirow[t]{4}{*}{3.} & \multicolumn{5}{|c|}{ There is a positive orientation towards small family size among educated couples } \\
\hline & Yes & $209(54.4)$ & $68(17.7)$ & $34(8.9)$ & $x^{2}=29.496(\mathrm{p}=0.000)$ \\
\hline & No & $16(4.2)$ & $21(5.5)$ & $6(1.6)$ & \\
\hline & Uncertain & $10(2.6)$ & $11(2.9)$ & $9(2.3)$ & \\
\hline \multirow[t]{4}{*}{4.} & \multicolumn{5}{|c|}{ Contraceptive use is high among the educated couples } \\
\hline & Yes & $209(54.4)$ & 79 (20.6) & $33(8.6)$ & $x^{2}=22.608(\mathrm{p}=0.000)$ \\
\hline & No & $20(5.2)$ & $13(3.4)$ & $7(1.8)$ & \\
\hline & Uncertain & $6(1.6)$ & $8(2.1)$ & $9(2.3)$ & \\
\hline \multirow[t]{4}{*}{5.} & \multicolumn{5}{|c|}{ Educated couples have more awareness about the effects of family size } \\
\hline & Yes & $219(57.0)$ & 83 (21.6) & $36(9.4)$ & $x^{2}=22.157(\mathrm{p}=0.000)$ \\
\hline & No & $13(3.4)$ & $8(2.1)$ & $8(2.1)$ & \\
\hline & Uncertain & $3(0.8)$ & $9(2.3)$ & $5(1.3)$ & \\
\hline \multirow[t]{4}{*}{6.} & \multicolumn{5}{|c|}{ Educated couples have more communication with one another about family size } \\
\hline & Yes & $218(56.8)$ & $74(19.3)$ & $29(7.6)$ & $x^{2}=45.347(\mathrm{p}=0.000)$ \\
\hline & No & $10(2.6)$ & $12(3.1)$ & $7(1.8)$ & \\
\hline & Uncertain & $7(1.8)$ & $14(3.6)$ & $13(3.4)$ & \\
\hline \multirow[t]{4}{*}{7.} & \multicolumn{5}{|c|}{ Educated couples are more exposed to new values or ideas regarding family size } \\
\hline & Yes & $200(52.1)$ & $67(17.4)$ & $28(7.3)$ & $x^{2}=30.139(\mathrm{p}=0.000)$ \\
\hline & No & $19(4.9)$ & $15(3.9)$ & $6(1.6)$ & \\
\hline & Uncertain & $16(4.2)$ & $18(4.7)$ & $15(3.9)$ & \\
\hline \multirow[t]{4}{*}{8.} & \multicolumn{5}{|c|}{ Educated couples have more access to family planning services } \\
\hline & Yes & $210(54.7)$ & $76(19.8)$ & $33(8.6)$ & $x^{2}=29.333(\mathrm{p}=0.000)$ \\
\hline & No & $14(3.6)$ & $8(2.1)$ & $2(0.5)$ & \\
\hline & Uncertain & $11(2.9)$ & $16(4.2)$ & $14(3.6)$ & \\
\hline \multirow[t]{4}{*}{9.} & \multicolumn{5}{|c|}{ Educated couples adopt contraceptives earlier than illiterate } \\
\hline & Yes & $215(56.0)$ & $84(21.9)$ & $21(5.5)$ & $x^{2}=73.488(p=0.000)$ \\
\hline & No & $10(2.6)$ & $9(2.3)$ & $10(2.6)$ & \\
\hline & Uncertain & $10(2.6)$ & $7(1.8)$ & $18(4.7)$ & \\
\hline
\end{tabular}

\section{CONCLUSION}

A decline in fertility was the major trend found in the study area. A very large number of the respondents not only called the small family a norm nowadays but also preferring small family over the large one in a society where most of the people were still considering more children as the blessing of God. They believed it is better to have less but more productive children than more but unproductive. Several factors affected the formation of such an attitude. The most important among these was education as it was significantly associated with a reduction in family size. Educated couples had a positive orientation towards small family size. This was supplemented by high contraceptive use, more awareness, and exposure to new values regarding family size along with more communication among the couples about family size and access to family planning services. They also tend to adopt the innovations earlier than illiterate couples. The study recommends enhancing the process by improving the literacy ratio, status, and access to information promoting family size through a more organized and specific campaign through the allocation of more funds and enhancing the access of target couples to contraceptives and family planning centers.

\section{LIMITATION AND STUDY FORWARD}

Despite consistency with the previous study the present study had some limitations. For example, several unknown factors can be involved in decreasing family size. Education alone could not grasp the total reality that how literacy levels decline the fertility level. Thus this study cannot be generalizing to a large extent. However, researchers can further explore more aspects regarding ethnicity, family social, and economic standings that tremendously influence family size.

\section{ACKNOWLEDGEMENT}

During this study, there was no conflict of interest among co-authors, and with any other published work, we the coauthors attest that the current research study is genuine work. Further, this study is not supported by any funding agency.

\section{AUTHORS CONTRIBUTION}

Muhammad Jawad and Aman Ullah conceived of the presented idea. Both authors developed the paper. Seema Zubiar carried out a statistical analysis. Saima Sarir thoroughly readout the paper and removed grammatical mistakes. Alamgeer 
khan did a lot of work in data collection. All authors discussed the results and contributed to the final manuscript.

\section{REFERENCES}

1. Akmam, W. (2002). Women's education and fertility rates in developing countries, with special reference to Bangladesh. Eubios Journal of Asian and International Bioethics, 12(4), 138-143.

2. Åslund, O., \& Grönqvist, H. (2010). Family size and child outcomes: Is there really no trade-off? Labour Economics, 17(1), 130-139. https://doi.org/10.1016/j.labeco.2009.05.003

3. Basu, A. M. (1999). Fertility Decline and Increasing Gender Imbalance in India, Including a Possible South Indian Turnaround. Development and Change, 30(2), 237-263. doi:https://doi.org/10.1111/1467-7660.00116

4. Basu, A. M. (2002). Why does Education Lead to Lower Fertility? A Critical Review of Some of the Possibilities. World Development, 30(10), 1779-1790. https://doi.org/10.1016/S0305-750X(02)00072-4

5. Bauer, G., \& Kneip, T. (2014). Dyadic fertility decisions in a life course perspective. Advances in Life Course Research, 21, 87-100. https://doi.org/10.1016/j.alcr.2013.11.003

6. Berrington, A., \& Pattaro, S. (2014). Educational differences in fertility desires, intentions and behaviour: A life course perspective. Advances in Life Course Research, 21, 10-27. https://doi.org/10.1016/j.alcr.2013.12.003

7. Bhargava, A. (2003). Family planning, gender differences and infant mortality: evidence from Uttar Pradesh, India. Journal of Econometrics, 112(1), 225-240. https://doi.org/10.1016/S0304-4076(02)00162-8

8. Borenstein, E., Kendal, J., \& Feldman, M. (2006). Cultural niche construction in a metapopulation. Theoretical Population Biology, 70(1), 92-104. https://doi.org/10.1016/j.tpb.2005.10.003

9. Carl, H. (2006). World Population Data Sheet of the Population Reference Bureau (Washington, DC: Population Reference Bureau, 2006).

10. Cooper, D. R., Schindler, P. S., \& Sun, J. (2006). Business research methods (Vol. 9): Mcgraw-hill New York.

11. Götmark, F., \& Andersson, M. (2020). Human fertility in relation to education, economy, religion, contraception, and family planning programs. BMC public health, 20(1), 1-17.

12. Gwako, E. L. M. (1997). Married women's ideal family size preferences and family planning practices: Evidence from rural Kenya. The Social Science Journal, 34(3), 369-382. https://doi.org/10.1016/S03623319(97)90035-5

13. Ihara, Y., \& W. Feldman, M. (2004). Cultural niche construction and the evolution of small family size. Theoretical Population Biology, 65(1), 105-111. https://doi.org/10.1016/j.tpb.2003.07.003

14. Jejeebhoy, S. J. (1995). Women's education, autonomy, and reproductive behaviour: Experience from developing countries. OUP Catalogue.

15. Kaboudi, M., Ramezakhani, A., Manouchehri, H., \& Hajizadeh, E. (2013). Relationship between age of marriage, women's education and fertility 1954-93: A study in the west of Iran. Biosciences Biotechnology Research Asia, 10(2), 855-860. doi:10.13005/bbra/1207

16. Kakar, Z. K., Khilji, B. A., \& Ullah, Z. (2011). Effect of female education on family size in Pakistan: a case study of Quetta city. Journal of international academic research, 11(2), 37-41.

17. Kamal, A., \& Pervaiz, M. K. (2011). Factors Affecting the Family Size in Pakistan: Clog-log Regression Model Analysis. Journal of Statistics, 18(1).

18. Lloyd, C. B., Kaufman, C. E., \& Hewett, P. (2000). The Spread of Primary Schooling in sub-Saharan Africa: Implications for Fertility Change. Population and Development Review, 26(3), 483-515. https://doi.org/10.1111/j.1728-4457.2000.00483.x

19. Mandl, C. E. (2019). Diffusion of Innovations: The Much Sought After Tipping Point. In Managing Complexity in Social Systems (pp. 155-162): Springer.

20. Marcén, M., Molina, J. A., \& Morales, M. (2018). The effect of culture on the fertility decisions of immigrant women in the United States. Economic Modelling, 70, 15-28. https://doi.org/10.1016/j.econmod.2017.10.006

21. Mari Bhat, P. N. (2002). Returning a Favor: Reciprocity Between Female Education and Fertility in India. World Development, 30(10), 1791-1803. https://doi.org/10.1016/S0305-750X(02)00065-7

22. Martin, T. C. (1995). Women's education and fertility: results from 26 Demographic and Health Surveys. Studies in family planning, 187-202. https://doi.org/10.2307/2137845

23. Morita, M., Ohtsuki, H., Sasaki, A., \& Hiraiwa-Hasegawa, M. (2012). Factors affecting the number of children in five developed countries: a statistical analysis with an evolutionary perspective. Letters on Evolutionary Behavioral Science, 3(1), 7-11.

24. Murthi, M. (2002). Fertility change in Asia and Africa. World Development, 30(10), 1769-1778.

25. Owuamanam, T. O., \& Alowolodu, O. (2010). Educational pursuit and income as correlates of family size in Ondo State, Nigeria. Journal of Social Sciences, 23(2), 123-127. https://doi.org/10.1080/09718923.2010.11892820

26. Pirinçci, E., \& Oguzöncül, A. F. (2008). Knowledge and attitude of married Turkish men regarding family planning. The European Journal of Contraception \& Reproductive Health Care, 13(1), 97-102.

27. Sámano, R., Martínez-Rojano, H., Chico-Barba, G., Sánchez-Jiménez, B., Sam-Soto, S., Rodríguez-Ventura, A. L., . . S Sclavo-Melo, S. (2019). Sociodemographic factors associated with the knowledge and use of birth control methods in adolescents before and after pregnancy. International journal of environmental research and public health, 16(6), 1022. 
28. Sekaran, U., \& Bougie, R. (2016). Research methods for business: A skill building approach: John Wiley \& Sons.

29. Sikandar, R., Khwaja, R., Shaikh, F., \& Jatoi, N. (2012). Fertility preferences among women of reproductive age in an underdeveloped country. Medical Channel, 18(1).

30. Steer, L., \& Wathne, C. (2010). Donor financing of basic education: Opportunities and constraints. International Journal of Educational Development, 30(5), 472-480.

31. Tropf, F. C., \& Mandemakers, J. J. (2017). Is the association between education and fertility postponement causal? The role of family background factors. Demography, 54(1), 71-91.https://doi.org/10.1007/s11150-0169357-6

32. Ullah, A., Ashraf, H., Tariq, M., Aziz, S. Z., Sikandar, K. U. R., Ali, N., . . Nisar, M. (2021). Battling the Invisible Infertility Agony: A Case Study of Infertile Women in Khyber Pakhtunkhwa-Pakistan. Journal of Ethnic and Cultural Studies, 8(2), 89-105.

33. Ullah, A., Ashraf, H., Tariq, M., Aziz, S. Z., Zubair, s., Sikandar, K. U. R., . . Nisar, M. (2021). Battling the Invisible Infertility Agony: A Case Study of Infertile Women in Khyber Pakhtunkhwa-Pakistan. 8(2). http://dx.doi.org/10.29333/ejecs/679

34. Ullah, A., \& Muhammad, N. (2020). Prevalence of mental health problems among youth involved in street crimes. Rawal Medical Journal, 45(4), 938-942. 